\title{
VRYHEID IN MENSLIKE IDENTITEITSVORMING EN SINBELEWING: ALTERNATIEWE VIR DETERMINISTIESE BENADERINGS
}

\author{
Magda van Niekerk \\ Dept. Afrikaans-Nederlands \\ Potchefstroomse Universiteit vir $\mathrm{CHO}$ \\ POTCHEFSTROOM
}

\begin{abstract}
Representatives of humanist approaches in psychology answer the basic quesfion of the meaningfulness of life by overemphasizing human frecdom, thereby differing from dcterminist schools. Man foms his own identity in an independent way, via the possibilities of a frec choice of objectives and ideals and by means of his freedom in adapting to circumstances. In this aricle the concepts of meaning and identity, as presented by four prominent humanist psychologists, are investigated. In spite of doing justice to the humanity of mon to a larger extent than in the case of determinist theories, humanist approaches fall shon of presenting an integrated view of man implied by the Biblical perspective on the central religious dimension of the existence of man Nevertheless, these theories entail insights that can be integrated into an own theory within the framework of the reformational paradigm.
\end{abstract}

\section{INLEIDING}

\subsection{Die grondliggende aard van die sinproblematiek}

Die sinproblematiek lewer een van die primêre lewensvrae waaroor elke mens, implisiet of eksplisiet standpunt moet inneem. Die bekende psigoloog Viktor Frankl, wat as't ware sy lewe gewy het aan 'n besinning rondom hierdie sinproblematiek, sê in sy Salzburg-lesings van 1977 dat gevoelens van leegheid en sinloosheid tot 'n wêreldwye fenomeen gegroei het, en hy verwys na psigologiese studies wat veelvuldige stawing verleen aan hipoteses dat dit selfs ten opsigte van die ontwikkelingslande geld (Frankl, 1985:22-23). Daarby is daar ook statisties aangetoon dat gevoelens van sinloosheid beduidend meer onder jongmense as onder ouer mense voorkom en dat dit aan die wortel van dwelmafhanklikheid, jeugmisdaad en selfmoord lê (Frankl, 1985:28-32). Die sinkrisis is volgens hom ook 'n grondelement in die pensioenerings- en middeljarekrisis, sodat hy tot die gevolgtrekking kom dat daar geen twyfel is oor die aktualiteit van die sinvraag en die akuutheid van die probleem van sinloosheidsgevoelens in ons tyd nie (Frankl, 1985:34, 36). 
Die sinvraag het van oudsher af bestaan, hoewel mense se reaksies hierop in die oorgrote meerderheid gevalle verbaal-ongeartikuleerd plaasvind. Dit gaan by die sinproblematiek nie net om die beskouings en standpunte van die mens nie, maar veral ook om sy praktiese lewensinstelling en lewenswyse, sodat menslike antwoorde op die sinvraag meestal 'n ongereflekteerde aard het.

Dit is egter nie net die mens in sy alledaagse leef en doen wat implisiet besig is om antwoorde op die sinvraag te "leef nie, maar ook in wetenskaplike teorieë is daar inherent ' $n$ sindimensie aanwesig en die verskillende -ismes in die wetenskappe dui juis op uiteenlopende moontlike reaksies hierop. Twee van die wetenskappe wat benaderings omvat wat wel eksplisiet oor die sinvraag nadink, is die filosofie as totaliteitswetenskap en die psigologie as vakwetenskap. Die klem in hierdie artikel val op psigologiese bydraes, waarby nie uit die oog verloor mag word dat filosofiese werklikheidsbeskouinge en mensbeelde aan die wortel hiervan lê nie.

\subsection{Valse sinbelewing}

Dit is waarskynlik nie toevallig dat daar juis in ons tegnies- en natuurwetenskaplikvooruitstrewende eeu toenemend die behoefte aan ' $n$ ware sinbelewing aangevoel word nie. Dit waarin die progressiwiste sedert die agtiende eeu sin wou lokaliseer, naamlik vooruitgang en vryheid deur middel van rasionele natuurbeheersing en die omsetting van natuurwetenskaplike ontdekkings in ekonomiese en tegnologiese mag, is immers as illusie ontmasker. Dit het gebeur in 'n lang proses van ontnugtering sedert die Napoleontiese nadraaie van die Franse Rewolusie en die sosiale ellendes en wantoestande wat deur die Industriële Rewolusie teweeggebring is, maar vervolgens ook in die twintigste eeu veral deur die twee wêreldoorloë, atoombomontploffings, omgewingsbesoedeling, kapitalistiese en kommunistiese uitbuiting, hongersnode en dergelike meer. Hierdeur is vele mense wat op grond van die mens se rasionele vermoëns 'n optimistiese vooruitgangsgeloof gehuldig het, as't ware wakker geskud tot erkenning van die feit dat juis die oorbeklemtoning van rasionaliteit, wetenskap en tegniek veroorsaak het dat 'n vollediger visie op die sin van ons bestaan en ons menslikheid verlore geraak het. Andersyds leef vele moderne mense tog ook op 'n merkwaardig onkritiese wyse voort binne die sciëntistiese tegnokratisme as een van die hoofstrominge in ons westerse wêreld.

Ook diegene wat hul vryheid op ander wyses wou verwerklik, byvoorbeeld deur 'n irrasionalistiese bandeloosheid en ontkenning van alle beginsels en norme, staan vandag veelal verslae ten aansien van wêreldprobleme soos Vigs, vervreemding van die samelewing, angs, depressiwiteit en 'n algemene gebrek aan sinbelewing. 'n Grype na hallusinatoriese middele, of andersins na nuwe outoritêre oplossings (soos merkbaar is 
in die opbloei van Oosterste godsdienste onder baie Europese jeugdiges wat hulle gewilliglik onderwerp aan die gesag van een of ander Oosterse ghoeroe) bied slegs 'n illusionêre uitweg. In werklikheid is hierdie alternatiewe weinig minder as noodkrete van mense wat hul identiteit kwytgeraak het as gevolg van 'n gebrek aan sin en lewensrigting.

\subsection{Agtergronde tot die personalistiese benaderings}

In hierdie situasies waarin 'n gebrek aan lewensrigting ervaar word, poog die personalistiese psigologie om die moderne mens op 'n weldeurdagte en empaties-sensitiewe wyse te stimuleer in sy soeke na sin, en om hom daardeur tot hulp te wees in die vestiging van sy eie identiteit sowel as in die vermyding van patologiese toestande. Die sentrale rol wat die konsep identiteit in hierdie teorieë oor persoonlikheidsontwikkeling speel, is opvallend, en identiteit word ten regte gekoppel aan tipies menslike motiverings en ideale wat inderwaarheid verband hou met die mens se lewensbeskouing, werklikheidsopvatting of -visie. Laasgenoemde bevat myns insiens implisiet altyd 'n antwoord op die sinvraag, al is dit 'n negatiewe of 'n skeptisistiese antwoord, of in uiterste gevalle ' $n$ totale ontkenning van die sin van die bestaan.

In teenstelling met die dieptepsigologie en die behaviorisme, waar besondere klem gelê word op die gedetermineerdheid van menslike gedrag (vergelyk Van Niekerk. 1991), hetsy deur onbewuste drange of eksterne omgewingsfaktore, word in die sogenaamde 'Third force psychology' sedert die vyftigerjare, veral in die fenomenologiese, eksistensiële en 'humanistiese' 1 psigologiese teorieë eerder die mens se vrye wilskeuse, selfdeterminering en selfaktualisering beklemtoon. Kruisbestuiwing tussen hierdie hoofkategorieë het gelei tot 'n getemperde determinisme by neo-Freudiane en neo-behavioriste, wat in kern egter nie versoenbaar is met die uitgangspunte van die personalisties-humanistiese rigtings nie.

Reeds die Gestaltpsigoloë was al bewus van die eensydighede van die behavioriste. ${ }^{2}$

\footnotetext{
${ }^{1}$ Dic woord 'humanisties' word hicr in aanhalingstekens geplaas, aangesien dit in 'n ictwat enger sin as tot dusver gebruik word. Waar dic aanhalingstekens wegval, word dil gebruik as sambreclterm vir alle rigtings in dic 'Third force psychology'. Gewoonlik word laasgenoemde cgter nader gepresiscer as personalistics-humanistics (in onderskcid van deterministicshumanistiese rigtings) of kortweg as personalistics.

${ }^{2}$ Koffka (1950:319) kritisecr byvoorbecld dic opvatting van die behavioris, Tichener, dat dic menslike self of ego verklaar kan word as "kinaesihetic sensations from the lower trunk or from parts of the body in strained position".
} 
Teenoor laasgenoemde se uitbanning van die ego-begrip uit die psigologie ten gunste van sogenaamde objektiewe, empiriese feite, is Koffka as verteenwoordiger van die Gestaltpsigologie van mening dat die wetenskaplike wat slegs deur 'n mikroskoop kyk, nooit tot die ontdekking van die feitelike bestaan van so iets soos 'n gesig kan kom nie (Koffka, 1950:319). Hy wil ruimte laat vir die bestaan van 'n self as permanente subsisteem en organisator van die persoonlikheid (Koffka, 1950:342) waardeur per implikasie die mens se persooniikheidseenheid en identiteit gewaarborg word, maar sien die self nie in Bybelse sin as religieus gerig nie. Saam met sommige neobehavioriste en kognitiewe psigoloë wat die neo-behavioristiese tradisie voortgesit het, was die Gestaltpsigoloë wegbereiders vir 'n psigologie wat die aksent sou verplaas ná menslike vryheid in identiteitsvorming en sinbelewing.

Daar word vervolgens ondersoek ingestel na bydraes oor die sin- en identiteitsproblematiek, gelewer deur vier verteenwoordigers van daardie rigtings in die psigologie wat 'n grondliggende klem op vryheid as vertrekpunt het, ten einde beter sig te kry op hulle besondere alternatiewe vir deterministiese benaderings. ${ }^{3}$

\section{DIE BYDRAES VAN PERSONALISTIESE RIGTINGS OOR SIN EN IDENTI-} TEIT

Fenomenologiese, eksistensiële en 'humanistiese' psigoloë is van mening dat die individu se siening van die wêreld waarin hy lewe belangriker is as die sogenaamde objektiewe kenmerke van die omgewing. Sodoende word die individuele persoon gesien as die konstitueerder of skepper van sy wêreld en stuur hy self sy eie ontwikkeling as mens, sodat hy geensins 'n slagoffer van omstandighede buite sy beheer is nie. Terwyl sowel die psigoanalise as die behaviorisme die determinante van ontwikkeling in die persoon se verlede soek, beklemtoon die verteenwoordigers van die humanistiese rigtings in die psigologie dus die mens se potensiaal en die rol wat toekomsideale en -beplanning in 'n persoon se ontwikkeling speel. Die mens se selfaktualisering, sy strewe om sy vermoëns te ontwikkel en/of sy ideale te bereik, hou dikwels 'n vermeerdering van spanning in, sodat die model van drang- of spanningsvermindering wat deur sommige deterministiese psigologiese rigtings ter verklaring van menslike gedrag geponeer word, volgens die personaliste (byvoorbeeld Allport, 1961:568-569 en Frankl, 1985:37) nie opgaan nie.

\footnotetext{
${ }^{3}$ Uiteraard is daar ook die moontlikheid om vanuit 'n Christelike raamwerk 'n alternaticwe siening van sin en identiteit na vore te bring. Dit val egter buite die bestek van hicrdie artikel.
} 


\subsection{Die fenomenologiese bydrae van Rogers}

In aansluiting by die fenomenologiese tradisie wat besondere klem lê op die fenomenale wêreld van die individu, sy persepsies en ervaringe van homself en van die wêreld (Rogers, 1965:532) werk die beroemde psigoterapeut Carl Rogers sy psigologiese beskouings uit. Rogers se beskouing beklemtoon die mens se uniekheid en die sentrale rol van sy subjektiewe ervaring (Rogers, 1972:111) asook 'n handhawing van die gedagte dat hy selfstandig aan sy eie lewe rigting en betekenis gee (Rogers, 1972:109).

Sentraal in Rogers se teorie staan die konsep van die self (Rogers, 1965:136-137) as 'n konseptuele patroon wat steeds in 'n dinamiese proses van verandering en ontwikkeling verkeer, in interaksie met die omgewing en met ander persone. Hy onderskei voorts tussen die selfkonsep (wat aandui hoe die individu homself sien en oor homself voel), die ware self (hoe die persoon werklik is, volgens sy werklike ervarings) ${ }^{4}$ en die ideale self (wat dui op hoe en wat die persoon graag wil wees). By die onderskeid tussen ' $n$ ware self en 'n ideale self kan positief aangesluit word, aangesien Rogers hiermee vanuit sy eie benadering rekenskap gee van die feit dat die mens in hierdie bedeling nog onderweg is. Hierdie onderweg wees kan vergelyk word met die Christen se eskatologiese visie op die mens as verloste sondaar wat eers wanneer Christus alles nuut gemaak het, werklik sy 'ideale self' sal wees - 'n volkome nuwe mens in Christus.

Belangrik is volgens Rogers (1965:150-151) dat die mens volgens sy eie waardestelsel moet handel en nie volgens ander maatstawwe wat hy van buite af opgeneem het ter wille van positiewe agting van ander persone nie. Dit beteken dat hy vry moet voel om al sy ervarings korrek te simboliseer ${ }^{5}$ (Rogers, 1954:258) en dat hy nie ter wille van die goedkeuring van of aanvaarding deur ander persone sy ervarings moet verdraai nie, aangesien dit juis ' $n$ valse selfkonsep en dus inkongruensie met die werklike ervarings tot gevolg het, wat op sy beurt weer lei tot 'n blokkasie van selfaktualisering. 'n Toestand van kongruensie daarenteen, verhoed wanaanpassing, interpersoonlike verhoudingsprobleme, spanning, frustrasie en konflik en skep vir die mens die moontlikheid om selfaktualiserend te wees en sy potensiaal ten volle te kan gebruik.

\footnotetext{
4 Hier moct egter gevra word of 'n persoon se ervarings werklik aan hom sy ware self kan openbaar, en of laasgenoemde nic ecrs kan geskied deur religieuse sclfbesinning, soos geinisicer deur Gods Woord nic.

5 Hierdie simbolisering is volgens Rogers iets anders as 'n werklike vitlewing van alle impulse en behocftes. Dit is myns insicns cgter problematies, soos blyk uit dic vraag of verbale uitlewing ook in sy mecs krassc vorme wel as simboliscring beskou kan word en indicn wel, of dic mens daarvoor, soos ook vir ander simboliscrings, verantwoordelik is vror God al dan nic.
} 
Hoewel selfagting as basis vir kreatiwiteit volgens Rogers (1954:257) afhanklik is van die positiewe agting en onvoorwaardelike aanvaarding van ander, laat hy tog ruimte daarvoor dat die handhawing van 'n positiewe selfkonsep later nie meer direk van die omgewing en van die oordele van ander afhanklik hoef te wees nie, maar slegs van die persoon se eie waardes. Afhangende van die aard van hierdie waardes, mag hulle myns insiens dui op die volkome outonoom gewaande mens of op die mens wat sy afhanklikheid van sy Skepper besef. Hiermee gee Rogers dus nie blyke van insig in die verband tussen ware selfkennis (en gepaardgaande selfaanvaarde waardes) en ware Godskennis nie. Hierdie gebrek aan insig blyk ook daaruit dat Rogers die realiteit van die sondeval onderbeklemtoon ${ }^{6}$ in sy beskouing aangaande die wesenlike goedheid van die mens. ${ }^{7}$ Voorts beklemtoon hy wel ten regte die belang van die self, maar laasgenoemde is vir hom, weens sy oortrokke klem op die dinamiese groei en ontwikkeling van die persoon, slegs 'n teoretiese konstruk, in teenstelling met die inhoud wat volgens ' $n$ reformatoriese standpunt daaraan gegee word, naamlik as die integrasiepunt van die menslike bestaan, soos gerig op die ware Oorsprong.

\section{$2.2 \quad$ Allport se selfteorie}

Gordon Allport $(1961: 127,252)$ vervang die term self met proprium, wat verwys na die mees sentrale, intieme deel van die mens se ervaringswêreld en wat betrekking het op die 'ek' of 'my'. Die mens se propriale (selfbetrokke) funksies begin as selfbewussyn reeds gedurende die eerste lewensjare ontwikkel ${ }^{8}$, en wel as'n bewuswording van die liggaamlike self, gevolg deur die ontwikkeling van selfidentiteit. Laasgenoemde is die besef dat die mens steeds dieselfde persoon bly, nieteenstaande die voortskryding van die tyd en veranderinge in liggaamsbeeld, rolvervulling en dergelike meer. In latere lewenstadia word hierdie identiteit weliswaar omvorm, afhangende van die wisseling van rolle en funksies soos ouerskap of die beroepsrol, maar die mens word daarmee

\footnotetext{
6 Vergelyk ook Botha (1990:146-148) in verband met Rogers se oorreaksic op Freud se klem op die sondigheid van die menslike natuur.

7 Volgens Rogers (1954:251) is die mens se strewe om sy potensiaal te ontwikkcl vanselfsprekend 'n heilsame krag in psigoterapic. Hy huldig dic standpunı dal die mens se kreatiwileil wesenlik konstruktief en sy gedrag goed sal wees, as hy erkenning verlecn aan al sy ervaringe (Rogers, 1954:252-253). Later sien hy die menslike grocipotensiaal binne gunstige omstandighede egter nie meer op so 'n onproblematiese wyse as 'n positiewe krag wat vanselfsprekend 'n positiewe onlwikkeling by alle mense tot gevolg het nic (vergelyk Botha, 1990:144)

8 Kyk Allport (1961:120-127) in verband met dic ontwikkeling van dic proprialc funksies in verskillende lewenstadia.
} 
nie iemand anders nie.

Reeds as jong kind beoordeel die mens mettertyd sy eiewaarde as persoon, 'n ontwikkeling wat sowel interaksie met die omgewing as ' $n$ groeiende onafhanklikheid noodsaak. In die volgende fase kom die verskynsel van selfuitbreiding by die kind na vore, wat dui op ' $n$ intieme betrokkenheid by sake wat vir hom van belang is, byvoorbeeld materiële besittings of die verhoudings waarin hy staan. ${ }^{9}$

Hierna volg die ontwikkeling van 'n selfbeeld as propriale funksie wat volgens Allport nie net 'n konsep omvat van die persoon aangaande dit wat hy is (onder andere sy persoonlikheid, sy vaardighede en sy voorkeure) nie, maar ook dit wat hy behoort te wees (volgens die eise wat ander aan hom stel) en dit wat hy graag wil wees (volgens sy eie wense en ideale). In die middelkinderjare begin die mens se rasionele self ontwikkel en ontstaan standpunte en persoonlike oortuigings, lewensbeplanning en eie verantwoordelikheid.

Die toppunt van menslike ontwikkeling, naamlik propriale strewing word volgens Allport egter bereik wanneer die persoon (tydens adolessensie of later) vir homself langtermyndoelwitte en -ideale stel en vervolgens sy lewe daarvolgens beplan en rig. Dit lei volgens hom tot optimale ontwikkeling. Allport (1961:134-137) skenk voorts ook aandag aan die ontwikkeling van die gewete vanaf ouerlike en sosiale kontrole na propriale kontrole. In laasgenoemde geval lei oortreding tot ' $n$ verlies aan selfwaarde en -agting, en speel vrees vir straf of sosiale sanksies nie meer 'n deurslaggewende rol nie.

Die verskillende ontwikkelingsfases is volgens Allport nie slegs relevant vir 'n beperkte tyd nie, maar behou hulle belang in die funksionering van die volwassene as totaliteit. Hulle vorm dan ook'n eenheid in die persoon se totale selfervaring. So bly byvoorbeeld by die volwassene die gevoel van selfidentiteit gehandhaaf en weet hy normaalweg wie hy is en wie hy wil wees, soos gelei deur bepaalde lewensideale. Die persoon se besef van selfidentiteit vorm dus 'n deurlopende lyn deur die totale lewensloop, ten spyte van tydsgebonde veranderinge.

In Allport (1961:365) se onderskeiding en hiërargiese ordening (van belangrik na minder helangrik) van kardinale, sentrale en sekondêre persoonlikheidstrekke weerspieël hy sensitiwiteit vir die stand van sake dat daar belangriker en minder belangrike

\footnotetext{
${ }^{9}$ Met hicrdic beskouing van Allport gee hy rekenskap van dic ontwikkeling van identitcit op 'n sekondêre vlak, wat moontlik met die term individualiseir getipecr kan word.
} 
motiverings in die mens se lewe is. Kardinale (allesoorheerdende, dominante) trekke word egter slegs aan bepaalde persone, 'n klein minderheid, toegeskryf, sodat hy ook hiermee nie 'n religieuse gerigtheid op die oog het nie. In die humanisme van sy teorie, waar die mens in homself die potensiaal besit om homself ten volle te verwesenlik (Allport, 1961:85) en waar hy onder leiding van sy selfbeeld en waardesisteem (waarin propriale strewing, dit wil sê sy selfbetrokke ideale 'n dominante rol vervul) rasioneel oor sake besluit, is daar egter weinig oog vir die religieuse dieptedimensie van die mens se identiteit - wat meer is as die uitkristallisering van die individuele persoon se plek in die wêreld, soos Allport (1961:252) dit omskryf. Hy kom weliswaar naby aan insig in die belang van 'n religieuse gerigtheid van die menslike selfheid en lewe, maar omdat hy nie werklik deurdring tot hierdie dimensie van die mens se ideale nie, word propriale strewing deur hom in 'n te groot mate vereenselwig met groot of duidelike ideale, sodat hy die bestaan van 'n religieuse lewensgerigtheid ook by die gewone mens met minder duidelik geartikuleerde ideale miskyk. Sy worsteling om die eenheid van die persoonlikheid te verklaar, 'n eenheid wat hy soek in propriale funksies (Allport, 1961:383) kan egter waardeer word.

\subsection{Maslow se teorie van behoeftes}

In teenstelling tot die behaviorisme en die psigoanalise, waar veralgemenings omtrent die mens gemaak word vanuit ondersoeke na respektiewelik dierlike gedrag en kliniese observasies van neurotiese pasiënte, sentreer Abraham Maslow se teorie rondom tipies menslike, normale funksionering. In die humanistiese psigologie van Maslow word veral die positiewe aspekte van menswees beklemtoon in 'n sintese van holistiese, dinamiese en kulturele benaderings (Masiow, 1954:ix, 26-31). In sy motiveringsteorie stel hy dat die mens eers nuwe behoeftes kan ervaar sodra meer basiese behoeftes bevredig is. Laasgenoemde is 'n noodsaaklike, maar nie voldoende voorwaarde vir die ontwikkeling van die hoër motiewe en behoeftes van selfaktualiserende persone, wat hy metamotivering noem (Maslow, 1973:314). Sodoende ontwerp hy 'n hiërargie van behoeftes ${ }^{10}$ vanaf die fisiologiese as die laagste, via die sekuriteits- en affiliasiebehoeftes, sodat die mens op 'n hoër vlak bewus word van erkenningsbehoeftes en hierna van selfaktualiseringsbehoeftes, dit wil sê die behoefte tot volle ontwikkeling van sy eie potensiaal (Maslow, 1954:80-92).11 Hy noem optimaal ontwikkelde persone selfaktua-

\footnotetext{
${ }^{10}$ Hy (Maslow, 1954:3; 1973:344) beklemtoon dat hierdie hicrargie nie as 'n waardehierargic opgevat mag word nie

${ }^{11}$ Frankl (1985:45) kritisecr Maslow deur daarop te wys dat die sinvraag nic ecrs na vore tree wanneer die lacre behoeftes bevredig is nie maar, soos hy uit cic crvaring kon getuig, ook in konsentrasickampe en selfs op die sterfbed.
} 
liseerders en hulle is mense wat ter wille van hul eie integriteit weerstand bied teen enkulturasie (Maslow, 1954:144), dit wil sê hulle behou 'n innerlike afstand teenoor die kultuur wat hulle omring (Maslow, 1954:224). Maslow (1954:83; 1973:313) beklemtoon nie net die funderende rol wat die bevrediging van die laervlak- of gebreksbehoeftes ten opsigte van die ontwikkeling van selfaktualisering as groeibehoefte speel nie, maar ook die regressie wat plaasvind wanneer die bevrediging van hierdie laere behoeftes eensklaps aan frustrasie blootgestel word. In verband met die selfaktualiseerder moet volgens Maslow (1973:314) die volgende belangrike vrae gestel word:

What motivates the self-actualizing person? What are the psychodynamics in self-actualization? What makes him move and act and struggle? What drives (or pulls) such a person on? What attracts him? For what does he hope? What makes him angry, or dedicated, or self-sacrificing? What does he fecl loyal to? Devoted in? What does he value, aspire to and yearn for? What would he dic (or live) for?

Hierdie vrae dui myns insiens op sake wat van sentrale belang is in die kompleks van lewensoortuigings van die selfaktualiseerder. Die vraag ontstaan egter of hierdie vrae werklik net tot selfaktualiseerders beperk moet word, en of dit nie algemeen-menslike vrae is wat ook in verband met nie-selfaktualiserende persone gestel kan word nie, sou die antwoorde daarop dan ook nie in alle gevalle ewe eenduidig wees en ewe maklik vasgestel kan word nie.

Ook in Maslow se teorie kan verskeie positiewe momente wat in 'n eie antropologiese raamwerk geplaas kan word, opgemerk word, byvoorbeeld die feit dat die mens se fisiese, biotiese en psigiese substraat funderend is vir die normatiewe struktuur waarin sy hoëre, tipies menslike behoeftes manifesteer, asook die feit dat die mens steeds in interaksie met sy omgewing staan en daardeur in staat is tot relatiewe verandering. Volgens sy teorie bestaan die menslike identiteit ten diepste in sy vermoë tot vrye, selfaktualiserende wilskeuses op die basis van bevrediging van sy gebreksbehoeftes, maar tot watter mate selfaktualisering ook al gekoppel is aan menslike waardes (Maslow, 1973:330), bly laasgenoemde tog op 'n bloot tydelike menslike vlak, deurdat hulle ten slotte herlei kan word na die mens se behoefte om siekte (in 'n breë sin) te vermy en menslike groei te bevorder (Maslow, 1973:331). Ook hierin is 'n Bybelse visie op 'n sentrale religieuse identiteit afwesig, ${ }^{12}$ asook ' $n$ visie op die ware aard van

konsentrasiekampe en selfs op dic sterfbed.

12 'n Uitvlocisel en simploom hiervan is dat Maslow (1954:88) godsdiens beskou as 'n verskynsel wal meestal 'n uitdrukking van menslike sekuriteitsbehoeftes is, en godsdienstigheid as iets wat gewoonlik verminder in dieselfde mate as wat die mens se selfagling en -vertroue toeneem (Maslow, 1954:25). Godsdicns as produk van dic behoefte aan selfaktualisering kom volgen hom (Maslow, 1954:221) wel voor, maar godsdienslige selfaklualiscerders hantecr God as 'n metafisicse konsep en nic as 'n persoonlike figuur nic. 
menslike vryheid en die realiteit van die sondeval. Sy humanistiese vertrekpunte skyn ' $n$ insig in die mens se religieuse verlange na God, wat anders en dieper is as tydelike behoeftes aan sekuriteit en selfaktualisering, te blokkeer. In die plek van 'n Bybelse visie op die sin van die menslike bestaan, vereenselwig hy die mens se behoefte aan sin en bestaansbetekenis met selfaktualisering. ${ }^{13}$

\subsection{Frankl se eksistensiële bydrae}

In Viktor Frankl se beskouings rondom die sinvraag kritiseer hy nie net die deterministiese benaderings ${ }^{14}$ waarvolgens menslike gedrag reduksionisties ${ }^{15}$ verklaar word as afreagering van drange of as reaksie op stimuli nie (Frankl, 1985:47), maar verwoord hy ook ernstige kritiek op die humanistiese gedagte van selfaktualisering, wat volgens hom 'n gefrustreerde strewe na sinvervulling verraai (Frankl, 1985:38). In die plek van selfverwerkliking as singewend, stel hy selftransendering - eers in die diens aan 'n saak, in die ervaring van (liefde tot) 'n medemens en in die sinvolle gestaltegewing aan lyding word die mens waarlik mens, en hierdeur word geluk die mens se deel (Frankl, 1985:61, 106).

Volgens Frankl (1963:207) kan die mens enige omstandigheid, selfs die haglikste en selfs sy eie geskiedenis transendeer en moet die vraag na die sin van die lewe omgekeer en geherformuleer word tot die vraag watter sin die mens aan die lewe kan gee

13 Kontrasteer hiermee Ouweneel (1984:124) se stelling dat dit by die Christen nic gaan om selfverwerkliking nie, maar om die verwerkliking van die verhouding lot God en die ontplooiing van die nuwe lewe in Christus.

14 Frankl (1985:171) rig veral sy aanvalle ıcen dic 'nihilistiesc indoktrinasic' en Icen dic dicplepsigoiugicse ontmaskeringsmanic wat nic bercid is om halt te roep met dic ontmaskering by dit wat eg menslik is nic, waardeur volgens hom juis 'n tendens tot ontmensliking van die mens na vore kom: "Der Psychologe aber, der auch dort nicht aufhoren kann zu entlarven, entlarv nur die ihm unbewusste Tendenz, das Echte im Menschen, das Menschliche im Menschen, zu entwerten." Vergelyk ook Frankl (1985:54). Dit is duidelik dat Frankl hiermec 'n besef van die mens se meta-tcoretiese uitgangspunte na vore bring.

15 Frankl (1985:51, 54-56) besıcmpel dic reduksionisme as 'n ignorering van dic mens se wil tot sin. Dit kom tot uiting in 'n deduksionisme: die mens se gedrag is dan niks anders as ' $n$ resultaat en produk van iets anders soos psigodinamicse, biochemicse, sosio-ckonomiesc of lecrprosesse nic. Dit werk fatalisme en 'n ontduiking van verantwoordelikheid in die hand. Die reduksionisme is volgens hom dic nihilisme van vandag - dit praat nie meer van die 'niks' nie, maar van die 'niks anders as', wat onafwendbaar tot nihilistiese konsekwensies lei. 
(Frankl, 1963:122). 'n Sinvolle en verantwoordelike lewe begin eers daar waar die mens deur pyn en lyding van sy selfsug verlos word. Die wêreld lewer vir die mens die motiewe wat hom tot sinvolle handelinge uitnooi (Frankl, 1985:46). Juis daar waar die mens voor' $n$ situasie te staan kom wat hy nie kan verander nie, kry hy die geleentheid om bo homself uit te styg, te groei, tot groter rypheid te kom. En sy vryheid bestaan in alle noodgedwonge situasies daarin dat hy steeds kan besluit wat in geestelike sin van hom sal word (Frankl, 1985:66). Die mens wat hierdie vryheid selftransenderend verwerklik, gee volgens Frankl aan die werklıkheid sin.

In Frankl se holistiese mensbeskouing vorm die geestelike aspek van die mens sy eksistensiële, spesifiek menslike kern (Frankl, 1963:160; 1970:136) wat eenheid en heelheid konstitueer en dus die mens se geïntegreerde funksionering verklaar. Hierdie geestelike aspek is die mens se wil-tot-sin (Frankl, 1970:66; 1963:154 e.v.) met ander woorde sy dinamiese vermoë om uit te reik na iets buite homself, getipeer as logos, wat letterlik beteken sin, woord of warheid. Ter wille hiervan is die mens in stat om te lewe, maar ook om te sterwe. Word hy egter verhinder om sy roeping of taak in die lewe te volbring, is hy onderworpe aan eksistensiële frustrasie wat tot 'n eksistensiële neurose aanleiding kan gee (Frankl, 1970:66-67).

In werklikheid stuit Frankl hiermee op die mens se religieuse gerigtheid op die Oorsprong of op 'n valse, vermeende oorsprong wat deur verteenwoordigers van 'n reformatoriese benadering in die filosofie beklemtoon word en wat aan die mens se ideale en waardes rigting en stukrag gee, sodat hy 'n diepe behoefte ervaar om in sy handel en wandel daaraan uiting te gee. Interessant is ook sy stelling dat sin nie alleenlik iets is wat die mens self aan die situasie gee nie, maar dat dit die mens ook van buite af konfronteer (Frankl, 1963:157). Hierdie opvatting herinner aan die reformatoriese beskouing dat die werklikheid $\sin$ is (Dooyeweerd, 1953:4), hoewel Frankl nie 'n spesifiek Christelike konnotasie hieraan heg nie. Hy verwys ook by geleentheid na dit wat agter die individuele ervaring van sin geleë is, die Meta-Sinn of Ueber-Sinn, en dit is iets waaraan die mens slegs kan glo (Frankl, 1985:71-72). Indien hy besluit om geloof te hê in 'n Ueber-Sinn, sê Frankl (1985:124), het dit 'n kreatiewe uitwerking op die mens, want dan maak hy dit waarin hy glo, ook waar vir ander en kom hy die bloot individuele waarheid te bowe.

Dit wil voorkom asof Frankl, ten spyte van sy eksistensialistiese oorbeklemtoning van die wording van die vrye individu in sy unieke situasie en die eenmaligheid van iedere sinverwerkliking ${ }^{16}$ tog waardering toekom vir sy besondere besef van die samehang

16 Vergelyk Frankl (1985:60): "Jeder Tag, jede Stunde wartet also mit einem neuen Sinn auf, und auf jeden Menschen wartet ein besonderer Sinn." Hicrdeur onderbeklemtoon hy die gemeenskapsaard van religicus gerigte menslike groeperings met hul onderskeie ideale. 
tussen die sin- en identiteitsproblematiek, soos blyk uit sy stelling: "Letzten Endes sind die Identitătskrisen - Sinnkrisen." Hy beklemtoon dat hierdie sin ook 'n subjektiewe aangeleentheid is en gesien moet word in terme van die spesifieke sin van 'n persoonlike lewe in 'n gegewe situasie waar die unieke persoon vir homself 'n sinvolle doelstelling, saak of taak in die lewe moet vind (Frankl, 1963:122, 159, 172). Frankl $(1963: 153,163)$ sien die terapeutiese proses in die eerste plek as logoterapie, wat beteken dat die terapeut die opdrag het om die pasiënt by te staan om 'n persoonlike sin in die lewe te ontdek (Frankl, 1970:44). Dit geskied deur die pasiënt se visie te verbreed. sodat hy bewus kan raak van die hele sin- en waardespektrum wat bestaan (Frankl, 1963:174). Die mens moet homself dus in keusevryheid en verantwoordelikheid transendeer na ' $n$ sin wat buite homself geleë is, na dit wat vir hom betekenis of $\sin$ in die lewe het, en as neweproduk van hierdie selftransendensie vind selfaktualisering plaas (Frankl, 1963:204). Hy sien laasgenoemde egter nie as 'n doel op sigself nie - trouens, selfaktualisering as doel op sigself en ten koste van die naaste, werk juis vernietigend op die mens se bestaan in en is gedoem tot mislukking.

'n Noodsaaklike voorwaarde vir geestesgesondheid is volgens Frankl (1963:164-167) nie homeostase nie, maar juis die dinamiese spanning wat teweeggebring word deur die mens se soeke na sin, waardeur hy selfs die eenvoudigste taak met oorgawe en op 'n selftransenderende, intensionele, roepingsbewuste wyse aanpak (Frankl, 1969:48). Dit kan alleenlik gebeur indien die mens nie 'n eksistensiële vakuum (Frankl, 1963:167-169), 'n innerlike leegheid in die kern van sy bestaan het nie. Die eksistensiële vakuum lê ten grondslag aan die nihilisme van die moderne mens wat oortuig is dat die lewe sinloos is (Frankl, 1963:204), sodat hierdie mens, wat noodwendig besluite moet neem ${ }^{17}$ (Frankl, 1969:83) in werklikheid rigtingloos is. Dit hang saam met die feit dat sin, in teenstelling tot waardes, nie oordraagbaar is nie, maar individueel in die eenmalige situasie gevind moet word as 'n moontlikheid tot verandering van die werklikheid ${ }^{18}$ (Frankl, 1985:59-60). Hierdie individuele ervaring van sin is

Vergelyk ook Frankl (1985:85): "Alles liegt am cinzclnen Menschen, ungeachtet der allenfalls geringen Menge Gleichgesinnten ..."

17 Frankl (1985:24) beklemtoon dat die mens hom nic, soos dic dicr, op sy instink kan verlaat om te weet wat hy moet doen nic, maar ook nie mecr op dic tradisie nic. Hy is dus genoodsaak om selfstandig besluite te neem, dit wil sê as hy 'n outenticke bestaan wil voer en nic aan totalitarisme of konformisme ten prooi wil val, deur slegs te doen wat ander van hom verwag of wat dic mecrderheid doen nic.

18 In die konteks van Frankl se beskouings kan dit ook beteken dat die mens sy cic gecstclike ingesteldheid tecnoor die onveranderbare situasic waarmec hy gekonfrontecr word, in vryheid self kan bepaal. 
noodsaaklik indien die mens wil ontkom aan gevoelens van sinloosheid, dit wil sê aan die eksistensiële vakuum. Verveeldheid, apatie, neerslagtigheid en alkoholisme kan onder andere simptome van die eksistensiële vakuum wees, maar ook oorkompensasies (Frankl, 1963:170) soos magswellus, geldgierigheid en plesiersug ${ }^{19}$. Hiermee het Frankl insig geopenbaar in die feit dat obsessionele gedrag inderwaarheid wanhopige pogings kan wees om ware lewensvervulling te vind, en dat hierdie plaasvervangers vir sinbelewing of oorgawe aan of ontvlugting van sinloosheidsgevoelens allermins aan die mens vrede kan verskaf.

'n Deel van die mens se sinvolle selftransendering is volgens Frankl ook die roeping om lyding sinvol te verwerk, wat iets anders is as die eksistensialistiese aanvaarding van die sinloosheid van die lewe en van lyding (Frankl, 1963:188). Veral wanneer lyding die betekenis van 'n offer kry, kan die mens die sin daarin ontdek (Frankl, 1963:179). Daarenteen gaan lyding oor in wanhoop indien dit nie getransendeer word nie. Frankl (1985:33, 132) sluit in hierdie verband ook aan by Nietzsche se stelling: "Wer ein Warum zu leben hat, erträgt fast jedes Wie." Wat belangrik is, is nie die lyding as sodanig nie, maar wel die mens se ingesteldheid daarteenoor. Anders as Rogers wat die mens se selfaktualisering afhanklik stel van onvoorwaardelike aanvaarding en agting as noodsaaklike sielkundige klimaatstoestand, is die eksisterende mens volgens Frankl nie hiervan afhanklik nie, omdat hy as mens oor wilsvryheid en oor 'n selftransenderende potensiaal beskik om bo die negatiewe omstandighede en deur humor en heroïsme bo homself uit te styg (Frankl, 1969:16-17).

'n Individualisering van sin, soos Frankl (1963:72) voorstaan, is uiteraard iets anders as 'n subjektiwistiese relativering daarvan. Dat die mens 'n persoonlike ervaring van sin benodig, is inderdaad ' $n$ beskouing wat met vrymoedigheid onderskryf kan word, met dien verstande dat sin op Skriftuurlike standpunt nie individualisties gedui mag word nie, aangesien 'n visie op die sin van die werklikheid in 'n skeppingsomvattende betekenis hierdeur verlore sou raak, en omdat die mens ook altyd in 'n religieuse gemeenskap met geesgenote leef.

Ten spyte van die feit dat Frankl hom daarvan weerhou om sin in laasgenoemde betekenis van die woord te definieer, is dit nogtans duidelik dat hy'n besondere bydrae tot die besinning rondom die menslike sinproblematiek gelewer het en dat daar oor 'n breë front by hom aangesluit kan word. In hierdie verband maak De Vos (1987:180) die volgende belangwekkende opmerking:

19 By hierdic opvatting van Frankl kan sckerlik positicf aangesluit word, aangesien dic gemis aan 'n Bybelse hartsgerigtheid 'n lugleegte laat wat nic net dergelike simptome kan veroorsaak nic, maar wat ook dic deur kan open vir allerlei ideologice as afvallige hartsgerigthede. 
Met sy persoonlikheidsiening gesentreer rondom selftransendensie maak Viktor Frankl, as decl van dic humanistiese revolusic in dic siclkunde, dic deur oop vir 'n Christelike perspekticl in dic siclkunde. Dic mens wat homself verloor vir dic saak van Christus, sal homself ten volle kan aktualiseer en uitleef.

\section{SLOTSOM}

Dit is duidelik dat verteenwoordigers van psigologiese rigtings waar die klem op menslike vryheid, eerder as op sy gedetermineerdheid gelê word, die soeker na 'n antwoord op die sinvraag konfronteer met 'n verskeidenheid moontlike alternatiewe waardeur die menslikheid van die mens in 'n groter mate tot sy reg kom. Hierdie regstelling van die deterministiese benaderings verdien ongetwyfeld waardering, alhoewel die oorbeklemtoning van vryheid roep om 'n geintegreerde mensbeeld waarin ook die natuurlike strukture van die mens, sy fisiese, biotiese en psigiese strukture, sowel as die neerslag van allerlei oorerflike en omgewingsfaktore op hierdie strukture. en wel onder normatiewe leiding, verreken word. Hierdie mensbeeld moet veranker word in ' $n$ religieuse perspektief, met ander woorde in die besef dat die mens se hartsgerigtheid ' $n$ deurslaggewende rol speel in sy belewing van $\sin$ en in sy identiteitsbesef en -vorming.

Ook die antwoorde van die humanistiese rigtings op die sinvraag bly ten slotte vrae. Die rede hiervoor is dat die Psigologie nie werklik die kwessie van sin kan opklaar nie, en dat 'n bepaalde sin-opvatting reeds aan al die uiteenlopende psigologiese beskouings ten grondslag lê. ${ }^{20}$

Die vraag kan gevra word waarom dan hoegenaamd al hierdie teorieë ondersoek is ten opsigte van hul sienings van sin en identiteit. In antwoord hierop moet beklemtoon word dat wetenskaplikes van alle oortuigings hulle besig hou met dieselfde werklikheid. Ook die wetenskaplike wat nie binne 'n reformatoriese tradisie werk nie, kan op stande van sake stuit en kan dikwels op 'n briljante wyse fasette van die werklikheid analiseer. So is daar in die personalisties-humanistiese bydraes, soos trouens ook in getemperde deterministiese beskouings, belangrike waarheidsmomente vervat, naamlik in die reaksie teen die behavioristiese omgewingsdeterminisme en teen die Freudiaanse psigo-seksuele drangdeterminisme. Daarby dui die personaliste se beskouings ook op die erkenning van 'n persoonlike lewenskern van die individuele

\footnotetext{
20 Vergelyk Frankl (1985:72) se stclling "dass cs durchaus nicht cine Aufgabe der Wissenschaft
} ist, den umfassenden Sinn des Lebens oder gar der Welt zu finden". 
mens, wat nie net 'n persoon se hoogste en belangrikste waardes huisves nie, maar ook die samebindende element in sy ontwikkeling vorm. Nogtans dring hulle nie deur tot 'n Bybelse mensbeskouing waarin die religieuse gerigtheid van hierdie lewenskern op die ware of 'n vermeende oorsprong verreken word nie.

Die slotsom van die ondersoek aangaande sinbelewing en identiteitsbesef in die humanistiese teorieë is dat daar heelwat positiewe momente en aansluitingspunte vir'n eie beskouing gevind kan word, ${ }^{21}$ maar dat die humanistiese uitgangspunte 'n visie op die sinproblematiek as 'n saak wat die mens se diepste sentraal-religieuse motivering en werklikheidsbeskouing raak, blokkeer. Met sy verwysings na geloof in 'n Ueber-Sinn kom Frankl waarskynlik die naaste aan 'n Bybelse beskouing van al die teorieë. Sin word egter meestal vereenselwig met tydelike doeleindes, hetsy betrokke op die self of in die beste humanistiese teorieë ook op die ander. Die humanistiese visies op sin word egter nie verwoord op 'n spesifiek Christelike wyse wat die skepping as totaliteit omvat nie, sodat meestal slegs gepoog word om rekenskap te gee van die individuele ervaring van sin. Om hierdie redes blyk dit noodsaaklik te wees om te soek na 'n eie beskouing waarin die samehang tussen sin en identiteit in die verskillende dimensies daarvan duideliker na vore kom.

\section{BIBLIOGRAFIE}

ALLPORT, G.W. 1961. Pattern and Growth in Personality. New York: Holt, Rinehart and Winston. BOTHA, M.E. 1990. Metatcorctiese perspekticwe op die sosiale wetenskappe. Potchefstroom : PU vir CHO. (Welenskaplike bydraes, A, nr. 73.)

DE VOS, H.M. 1987. 'n Eksistensiële benadering tot persoonlikheid. (In Moller, A.T. red. Persoonlikhcidsiclkunde. Durban : Buttcrworth. p. 161-180.)

DOOYEWEERD, H. 1953 (1); 1955 (2); 1957 (3). A New Critique of Theorctical Thought. (Translated by D. Frecman and B. Young.) Philadelphia : The Presbytcrian and Reformed Publishing Co.

FRANKL, V.E. 1963. Man's Scarch for Meaning: An Introduction to Logotherapy. New York : Washington Square Press.

FRANKL. V.E. 1969. The Will to Meaning: Foundations and Applications of Logotherapy. New York World Publishing Co.

FRANKL, V.E. 1970. Psychotherapy and Existentialism: Sclected Papers on Logotherapy. London Souvenir Press.

FRANKL, V.E. 1985. Die Sinnfrage in der Psychotherapie. Munchen : Piper.

KOFFKA, K. 1950. Principles of Gicstalt Psychology. Londen : Routledge \& Kegan Paul.

21 Vergelyk ook Venter (s.a.:118) waar hy duidelik stel dat "(d)ie Christelike filosoof kan sonder vrecs ook gebruik maak van vrugbarc insigte by dic nic-Christclike filosoficë, ondat hy hullc betrcklike waarde kan erken binne dic raamwerk en tecn dic agtergrond van die religicuse grondmotief waaruit hulle opgckom het". 


\section{Vnheid in menslike identiteitsvorming en sinbelewing}

MASLOW, A.H. 1954. Motivation and Personality. New York : Harper.

MASLOW, A.H. 1973. The Farther Reaches of Human Nature. Harmondsworth : Penguin Books.

OUWENEEL, W.J. 1984. Psychologic: ecn christclijke kijk op het mentalc leven. Amsterdam : Buijten \& Schipperheijn.

ROGERS, C.R. 1954. Toward a Theory of Creativity. E.T.C.: A Review of General Semuntics, XI(4):249260 .

ROGERS, C.R. 1965. Client-centered Therapy: Its Current Practice, Implications and Theory. (With chapters contributed by E. Dorfman, T. Gordon and N. Hobbs.) Boston : Houghton Miffin.

ROGERS, C.R. 1972. Somc Observations on the Organization of Personality. (In L.akarus, R.S. and Opton Jr, E.M., eds. Personality: Sclected Readings. Harmondsworth : Penguin, p. 103-122.)

VAN NIEKERK, M. 1991. Determinisme en getemperde determinisme in trikulc psigologiese beskouings oor sin en identiteil. Koers, 56(2):123-138.

VENTER, E.A. s.a. Wysgerigc temas. Bloemfontein : SACUM. 